\author{
ANDRZEJ MATCZAK \\ Uniwersytet Łódzki \\ Wydział Nauk Geograficznych \\ Instytut Geografii Miast i Turyzmu
}

\title{
PROBLEMATYKA MIESZKALNICTWA W BADANIACH Profesora Jerzego DZieciuchoWicza
}

\section{HOUSING ISSUE IN THE RESEARCH OF PROFESSOR JERZY DZIECIUCHOWICZ}

Artykuł wpłynął do redakcji 04.02.2014 r.; po recenzjach zaakceptowany 24.02.2014 r.

MAtczAK A., 2014, Problematyka mieszkalnictwa w badaniach Profesora Jerzego Dzieciuchowicza [w:] Klima E. (red.), Ludność, Mieszkalnictwo, Ustugi - w 70. rocznice urodzin Profesora Jerzego Dzieciuchowicza. Population, Housing, Services $-70^{\text {th }}$ Anniversary of Professor Jerzy Dzieciuchowicz, „Space-Society-Economy" 13, Department of Population and Services Studies, Wydawnictwo Uniwersytetu Łódzkiego, Łódź, s. 107-126. /ISSN 1733-3180/

Prof. zw. dr hab. Andrzej Matczak, Uniwersytet Lódzki, Instytut Geografii Miast i Turyzmu, ul. Kopcińskiego 31, 90-142 Łódź;

e-mail: matczak@geo.uni.lodz.pl

\section{STRESZCZENIE}

W Polsce po II wojnie światowej przeprowadzono inwentaryzację stanu mieszkań w miastach. Prowadzono ją w ramach studium inwentaryzacji urbanistycznej. Do badań tych aktywnie włączył się łódzki ośrodek geograficzny. Geografowie z ośrodka łódzkiego przeprowadzili szereg studiów inwentaryzacji urbanistycznej w miastach Śląska Opolskiego, Kielc i Łodzi. Na ich podstawie przedstawiono szereg opracowań dotyczących zróżnicowania przestrzennego i szczegółowej rejonizacji warunków mieszkaniowych w paru miastach Śląska Opolskiego, centrum Kielc i w Łodzi. Badania te oparto na bezpośrednich kwerendach terenowych oraz na materiałach Narodowych Spisów Powszechnych (NSP). W badaniach tych 
aktywny udział brał Profesor Jerzy Dzieciuchowicz. Problematyka mieszkalnictwa, a zwłaszcza rejonizacja warunków mieszkaniowych w Łodzi, stanowiła w dorobku naukowym Profesora ważny nurt badawczy w okresie 1972-2012. Przeprowadzone w tym okresie studia empiryczne podsumowuje prezentacją systemowej propozycji badań w postaci szeroko ujętego modelu środowiska mieszkaniowego.

SŁOWA KLUCZOwE: miasto, mieszkalnictwo, rejonizacja warunków mieszkaniowych

\subsection{WPROWADZENIE}

Polska w okresie drugiej wojny światowej utraciła blisko 1/4 swoich zasobów mieszkaniowych. Wielkość zniszczeń wojennych substancji mieszkaniowej była zróżnicowana przestrzennie. Wiele miast uległo znacznie poważniejszym zniszczeniom (np. Warszawa, Wrocław), natomiast w innych zniszczenia te miały mniejszy rozmiar (np. Katowice, Łódź). Jednak ogólna sytuacja mieszkaniowa społeczeństwa polskiego po zakończeniu wojny była bardzo trudna. Zmiana ustroju państwa po 1945 r. diametralnie zmieniła warunki funkcjonowania gospodarki mieszkaniowej w Polsce. Nastąpiła likwidacja rynkowego obrotu gruntami i mieszkaniami. Mieszkanie stało się dobrem społecznym, a jego budowę i dystrybucję przejęło państwo (m.in. poprzez system spółdzielczości mieszkaniowej). Postępujący rozwój społeczno-gospodarczy kraju oparty o intensywną industrializację i urbanizację spowodował, że w końcu lat 80. XX wieku blisko $2 / 3$ społeczeństwa polskiego mieszkało w miastach. Należało mu zagwarantować przyzwoite warunki mieszkaniowe. Wymagało to stosownej polityki mieszkaniowej i olbrzymich nakładów inwestycyjnych na budowę nowych mieszkań. Natomiast potrzeby mieszkaniowe systematycznie rosły w całym okresie Polski Ludowej i nie zostały do końca zaspokojone. Cały wysiłek koncentrował się na budowie nowych mieszkań, pozostawiając problemy zagospodarowania ich otoczenia i wyposażenia w usługi na dalszym planie. Po kolejnych zmianach ustrojowych w 1989 r. Polska powróciła do gospodarki rynkowej. Zmianie uległy podstawy prawno-ekonomiczne gospodarki i budownictwa mieszkaniowego. Przywrócono rynkowy obrót gruntami i mieszkaniami, tym samym rozwinął się rynek nieruchomości. Budowę mieszkań i ich dystrybucję (wynajem, sprzedaż) przejął sektor prywatny. Państwo stara się w miarę możliwości wspierać budownictwo mieszkaniowe, jednak nie naruszając reguł rynkowych. 


\subsection{GENEZA I ROZWÓJ BADAŃ GEOGRAFICZNYCH PROBLEMATYKI MIESZKALNICTWA}

Przedstawione w zarysie zmiany ustrojowe w Polsce nie tylko kształtowały gospodarkę i politykę mieszkaniową kraju, ale również silnie oddziaływały na problematykę prowadzonych badań nad mieszkalnictwem. Badania te prowadziły i nadal prowadzą krajowe ośrodki reprezentujące takie dyscypliny naukowe, jak ekonomia, socjologia, architektura, urbanistyka, planowanie, geografia i in. W okresie Polski Ludowej konieczność masowej budowy nowych mieszkań wymagała stosownego przygotowania i uzbrojenia gruntów pod budownictwo mieszkaniowe, rozplanowania i wyposażenia budowanych osiedli mieszkaniowych, przyzwoitego standardu mieszkań w zakresie powierzchni, oświetlenia, wyposażenia sanitarno-higienicznego $\mathrm{i}$ in. Warunki te spełniały osiedla blokowe, pomimo nie najlepszego standardu technicznego mieszkań (małe powierzchnie, niedostateczne wyciszenie itp.) oraz wyposażenia ich, zwłaszcza w początkowym okresie funkcjonowania, w usługi. Współcześnie, osiedla blokowe w miastach Polski nadal posiadają duże zasoby mieszkaniowe w znaczącym stopniu decydując o warunkach mieszkaniowych Polaków. Sytuacja ta wpłynęła na zakres prowadzonych badań naukowych. Uwaga badaczy koncentrowała się na ocenie samego mieszkania, natomiast niewiele uwagi poświęcano kwestiom zagospodarowania bliższego i dalszego jego otoczenia. Dla tych badań podstawę źródłową stanowiły statystyki różnych instytucji obsługujących mieszkalnictwo (np. informacje pozyskiwane $\mathrm{w}$ zarządach spółdzielni mieszkaniowych) oraz pochodzące z Narodowych Spisów Powszechnych. W niewielkim zakresie, i to niemal wyłącznie $\mathrm{w}$ mikroskali, podejmowano badania dotyczące postaw, potrzeb i preferencji dotyczących samego mieszkania. Ten nurt analiz, wymagających badań ankietowych, najczęściej podejmowali socjolodzy (Jałowiecki 1968; Turowski $1979 \mathrm{i}$ in.). W niewielkim też stopniu zajmowano się rodzajem budynków oraz typem zabudowy mieszkaniowej. W opracowaniach architektów i urbanistów zwracano uwagę w nowo budowanych osiedlach blokowych na potrzeby człowieka odnośnie zagospodarowania przestrzennego osiedli, kompozycji ich krajobrazu itp. (Adamczewska-Wejchert 1977; Wejchert 1988 i in.), jednak ograniczone środki finansowe uniemożliwiały ich pełne wdrożenie w praktyce. Podejmowano też problem kosztów budowy i eksploatacji mieszkań i budynków w osiedlach blokowych.

Na tle badań zagranicznych, prowadzonych w tamtym okresie, była to bardzo ograniczona problematyka (Groeger 2013). Badacze zagraniczni również zwracali uwagę na problematykę mieszkania, ale w dużo szerszym zakresie analizując m.in. jakość wykonawstwa, usytuowanie mieszkań, ich izolację akustyczną, poczucie intymności $\mathrm{i}$ in. $\mathrm{W}$ systemie rynkowym dużą uwagę zwracano na wartość mieszkania i determinanty ją określające, co wymagało badań bliższego i dalszego otoczenia mieszkania, czego w polskiej literaturze 
naukowej niemal w ogóle nie podejmowano. Prowadzono też pogłębione studia w zakresie preferencji mieszkaniowych poszczególnych grup ludności, zwłaszcza będących w różnych okresach życia, typów zabudowy i jej wpływu na identyfikację z miejscem zamieszkania itp. (Groeger 2013). Obok tradycyjnego opisu empirycznego mieszkalnictwa, pojawiają się w literaturze anglojęzycznej coraz częściej analizy wartościujące. Podejście wartościujące w studiach mieszkalnictwa prowadzi do daleko posuniętej różnorodności postaw filozoficznych w podejmowanych badaniach. Analiza rynku mieszkaniowego ma m.in. przyczynić się do lepszego zrozumienia struktury społeczno-przestrzennej miasta. Na przykład, prowadzone badania $\mathrm{w}$ ramach nurtu radykalnego wskazują, że zróżnicowanie warunków mieszkaniowych nie jest wynikiem indywidualnych preferencji i wolnego wyboru ludzi, lecz jedynie ich reakcją w ramach istniejących możliwości (Harvey 1973). Określa je m.in. działalność menagerów, agentów budowlanych oraz wielu innych instytucji kontrolujących osiedlanie i przemieszczanie się ludności w mieście. Szereg opracowań zagranicznych koncentruje więc swoją uwagę na ograniczeniach narzucanych ludziom przez instytucje kontrolujące rynek mieszkaniowy (Gray 1975; Harvey 1975; Johnston 1977; Węcławowicz 1980).

Po 1989 r. w zmienionych warunkach ustrojowych ujawniły się nowe problemy wymagające szerszych badań interdyscyplinarnych problematyki mieszkalnictwa w polskich miastach. Duży udział w zabudowie wielkomiejskiej osiedli blokowych spowodował szersze zainteresowanie badaczy warunkami zamieszkania $\mathrm{w}$ nich. Zwrócono głównie uwagę na negatywne zjawiska społeczne mające miejsce w osiedlach blokowych. Prywatyzacja przestrzeni publicznej miast poprzez osiedla „grodzone”, procesy rewitalizacji i gentryfikacji i ich następstwa społeczne w miastach, przyszłość zabudowy blokowej i in. stały się często podejmowanymi problemami badawczymi (Bachvarov 2005; Mierzejewska 2006; Rydz, Szymańska 2007 i in.). Szerokich badań oraz dialogu społecznego wymaga problematyka dostosowania rozwiązań architektonicznych i urbanistycznych dla szybko różnicujących się potrzeb społecznych w zakresie mieszkalnictwa, których badania szybko rozwijają się w ostatnich latach. Punkt ciężkości badań nad mieszkalnictwem stopniowo przesuwa się na zagadnienia obejmujące bliższe i dalsze otoczenie mieszkania (wyposażenie w usługi, tereny dla rekreacji, dostępność komunikacyjna itp.). Rośnie też liczba opracowań podejmujących problematykę społecznego wartościowania i preferencji mieszkaniowych oraz ich przemian w Polsce (Szkurłat 2000; Madurowicz 2007; Dzieciuchowicz, Groeger 2012 i in.). Podejmowane badania naukowe i dyskusje społeczne wyraźnie oddziałują na zmianę konstrukcji normatywów architektoniczno-urbanistycznych, które skupiają się nie tylko na samym mieszkaniu, ale również $\mathrm{w}$ rosnącym zakresie na jego otoczeniu. $\mathrm{W}$ ten sposób problematyka polskich badań $\mathrm{w}$ zakresie mieszkalnictwa wyraźnie nawiązuje do badań światowych (Przesmycka, Pytlarz 2006). 
Problematyka mieszkalnictwa była zawsze i jest nadal obecna w badaniach z zakresu ekologii społecznej (czynnikowej) miast, waloryzacji przestrzeni miejskiej, percepcji miasta, warunków życia mieszkańców miast i in., będąc jedną z ważnych grup wskaźników wskazujących na zróżnicowania wewnątrzmiejskie. Sprzyja ona m.in. badaniom ilościowym, szerokim stosowaniu metod statystycznych, m.in. analizy czynnikowej, statystycznych metod typologicznych, metod skalowania indywidualnych różnic itp.

\subsection{GENEZA I ROZWÓJ BADAŃ MIESZKALNICTWA W ŁÓDZKIM OŚRODKU GEOGRAFICZNYM}

Po drugiej wojnie światowej ogrom zniszczeń spowodował konieczność inwentaryzacji stanu mieszkań $\mathrm{w}$ miastach Polski. Taką inwentaryzację prowadziły stosowne organy administracji państwowej, do której w ograniczonym zakresie włączali się też geografowie z krajowych ośrodków uniwersyteckich, w ramach studium inwentaryzacji urbanistycznej. Łódzki ośrodek geograficzny jako jeden z pierwszych włączył się do tych badań i można uznać go za pioniera geograficznych badań mieszkalnictwa w Polsce w tamtym okresie. Dotyczyły one analiz w skali całych miast, jak i pojedynczych osiedli mieszkaniowych (Suliborski 1970; Kucharska 1974; Dzieciuchowicz, Stolarczyk, Suliborski 1972). Badania mieszkalnictwa w ramach studium inwentaryzacji urbanistycznej przez łódzki ośrodek geograficzny zostały podjęte m.in. na terenie Śląska Opolskiego (Liszewski 1971; Pączka 1971). Zgromadzone wtedy materiały źródłowe posłużyły do szczegółowych opracowań naukowych i ich publikacji. W badaniach tych uczestniczyli pracownicy Zakładu Geografii Ekonomicznej, a wśród nich również Profesor Jerzy Dzieciuchowicz. Publikowane prace przede wszystkim podejmowały problem zróżnicowania przestrzennego i szczegółowej rejonizacji warunków mieszkaniowych w poszczególnych miastach (Prudnik, Niemodlin) lub w ich fragmentach (Kielce). Były to studia empiryczne w przeważającym zakresie bazujące na badaniach terenowych. Jednak już w pierwszych pracach ich autorzy podejmowali trud pewnych ustaleń teoretycznych odnośnie pojęć (warunki mieszkaniowe) i zakresu badań. We współautorskim studium (Dzieciuchowicz, Stolarczyk, Suliborski 1972) dotyczącym warunków mieszkaniowych centrum Kielc w ujęciu przestrzennym zdefiniowano pojęcie warunków mieszkaniowych i zakres ich badań. Pod pojęciem warunków mieszkaniowych autorzy ci rozumieli $\mathrm{w}$ odniesieniu do potrzeb ludności wielkość, stan, wyposażenie i zaludnienie substancji mieszkaniowej. Wprowadzili pojęcie wewnętrznych i zewnętrznych warunków mieszkaniowych. Na wewnętrzne warunki mieszkaniowe składało się zużycie, wyposażenie, wielkość i zaludnienie zabudowy mieszkaniowej. Niektóre składniki tych warunków odnosiły się do właściwości samych domów, inne do mieszkań oraz izb mieszkalnych, a jeszcze inne do mieszkańców korzystających z obiektów 
mieszkaniowych. Z kolei jako zewnętrzne traktowano warunki panujące na zewnątrz pomieszczeń użytkowanych na cele mieszkaniowe w miejscu zamieszkania ludności. Wyznacznikiem tych warunków była gęstość zaludnienia, koncentracja zabudowy mieszkaniowej oraz skupienie usług, które posłużyły do przeprowadzenia szczegółowej rejonizacji warunków mieszkaniowych na obszarze centrum Kielc. Autorzy w tym opracowaniu świadomie pominęli cechy dostępności komunikacyjnej, warunki rekreacji na terenach zielonych, odległość od placówek oświaty, kultury, położenia miejsc pracy itp., które nie wykazywały istotnej zmienności przestrzennej na badanym obszarze. Ten schemat teoretyczny badań przyjął J. Dzieciuchowicz w kolejnych opracowaniach dotyczących m.in. Niemodlina (1972) i Prudnika (1974b).

W 1976 r. A. Suliborski opublikował pierwszą próbę zdefiniowania środowiska mieszkaniowego miasta z punktu widzenia badań geograficznych oraz modelową koncepcję jego identyfikacji oparte na ujęciu systemowym. Autor ten środowisko mieszkaniowe określa, jako zbiór miejsc (punktów) zamieszkania, identyfikowany za pomocą zbioru istotnych dla człowieka elementów społecznych, ekonomicznych i przyrodniczych otaczających te miejsca oraz relacji zachodzących pomiędzy tymi elementami, jak również między nimi a miejscami zamieszkania. Środowisko mieszkaniowe, podobnie jak i przestrzeń mieszkaniowa interpretowane są w ujęciu systemowym. Należy ją badać w ramach czterech stref: 1) pierwszą stanowi mieszkanie, czyli obudowana część przestrzeni, przeznaczona dla jednej rodziny, 2) drugą jest budynek, który uzupełnia funkcję mieszkania i tworzy $\mathrm{z}$ nim jedną całość, 3) trzecią stanowi teren otaczający budynek, którego granice wyznacza nieruchomość, 4) ostatnią stanowi przestrzeń położona już poza granicami nieruchomości, której granice nie są ściśle określone i są zależne od rodzaju zabudowy i aktywności mieszkańców, ale znajduje się ona $\mathrm{w}$ zasięgu bezpośredniego kontaktu człowieka. Przestrzeń środowiska mieszkaniowego ze względu na zróżnicowanie formy, treści, funkcji i przestrzeni można podzielić na wewnętrzną zawierającą mieszkanie i budynek oraz zewnętrzną obejmującą nieruchomość i otoczenie miejsca zamieszkania.

W następnych latach problematyką środowiska mieszkaniowego w łódzkim ośrodku geograficznym zajmuje się J. Dzieciuchowicz (1974a, 1975, 1976, 1979, 1980, 1999, 2000, 2002, 2005, 2007a, 2007b, 2008, 2011a, 2011b, 2012), który publikuje szereg artykułów podejmujących problematykę szczegółowej i kompleksowej rejonizacji warunków mieszkaniowych ludności miejskiej Łodzi. W ostatnich latach problematyka ta została poszerzona o analizy zróżnicowania przestrzennego nieruchomości gruntowych i obrotu nimi w Łodzi oraz o studia struktury i typologii przestrzennej spółdzielczych, komunalnych i społecznych zasobów mieszkaniowych Łodzi. W okresie lat 70. i 80. XX wieku problematyka ta jest sporadycznie podejmowana poza łódzkim ośrodkiem geograficznym, m.in. przez W., M. Gaczek (1979) na temat struktury przestrzeni rezydencjonalnej Poznania, czy też przez M. Dutkowskiego i I. Sagan (1987) 
dotycząca zróżnicowania morfologicznego przestrzeni mieszkaniowej Sopotu. W końcu lat 80. XX wieku w łódzkim ośrodku geograficznym S. Liszewski (1995) sformułował koncepcję badania warunków życia mieszkańców miast, w ramach której S. Kaczmarek (1996) zaprezentowała studium struktury przestrzeni mieszkaniowej Łodzi. Wprowadziła pojęcie warunków zamieszkania obejmujących mieszkanie, dom i otoczenie. W analizie struktury przestrzennej warunków zamieszkania uwzględniła element percepcji. Problem oceny warunków zamieszkania w opinii mieszkańców jednego z łódzkich osiedli mieszkaniowych podejmował S. Marcińczak (2004), a w osiedlach blokowych E. Szafrańska $(2010,2011,2012)$, natomiast waloryzację przestrzeni mieszkaniowej w opiniach klientów łódzkich biur obrotu nieruchomościami przedstawiła L. Groeger (2004). E. Szkurłat (2000) przeprowadziła studia porównawcze na temat akceptacji miejsca zamieszkania młodzieży w trzech dużych miastach Polski. Problematykę gospodarki i budownictwa mieszkaniowego podejmował T. Marszał (1999), K. Milewska-Osiecka (2010), A. Ogrodowczych (2011). Pogłębienie ujęcia teoretycznego środowiska mieszkaniowego w łódzkim ośrodku geograficznym doczekało się ostatnio w opracowaniach J. Dzieciuchowicza (2011) i L. Groeger (2013). Po 1989 r. wzrosło zainteresowanie polskich geografów badaniami mieszkalnictwa, obecnie w wielu krajowych ośrodkach geograficznych prowadzone są w tym zakresie badania naukowe, np. w Warszawie, Poznaniu, Wrocławiu, Krakowie i in.

\subsection{BADANIA MIESZKALNICTWA W DOROBKU NAUKOWYM PROFESORA JERZEGO DZIECIUCHOWICZA}

Przeprowadzone przez Profesora Jerzego Dzieciuchowicza badania warunków mieszkaniowych w miastach Śląska Opolskiego (Niemodlin, Prudnik), Kielc oraz przede wszystkim Łodzi koncentrują się na problemie ich wewnątrzmiejskiego zróżnicowania przestrzennego (Dzieciuchowicz 1972, 1974b, 1975, 1979 i in.). Wynikiem przeprowadzonych analiz było z reguły opracowanie szczegółowej i kompleksowej rejonizacji warunków mieszkaniowych. Przeprowadzone rejonizacje poprzedzone są ogólną charakterystyką warunków mieszkaniowych obejmującą analizy rozwoju, struktury przedmiotowej i przestrzennej, funkcjonowania itp. całkowitych zasobów mieszkaniowych, a także, w postaci osobnych opracowań, ich składowych elementów obejmujących zasoby budownictwa spółdzielczego, komunalnego i społecznego. Uzupełniają je analizy struktury i typologii przestrzennej gruntów miejskich (nieruchomości gruntowych) w Łodzi przeprowadzone w przekroju 215 obrębów geodezyjnych (Dzieciuchowicz 2008) oraz analizy obrotu działkami, po części odzwierciedlającymi preferencje przestrzenne ich nabywców, w układzie 61 jednostek osiedlowych Łodzi. Są to przede wszystkim prace empiryczne. Bazują na wypracowanych na początku lat 70 . XX wieku pojęciach, 
w miarę upływu lat poszerzane i doprecyzowywane do zakresu prowadzonych badań, zwłaszcza pojęciu warunków mieszkaniowych w podziale na wewnętrzne i zewnętrzne. Pomiar i ocenę warunków mieszkaniowych określano z reguły na bazie wskaźników ilościowych, w analizach których wykorzystano szeroki wachlarz zróżnicowanych metod statystycznych (od wskaźników statystyki opisowej po statystyczne metody typologiczne) wraz z prezentacją kartograficzną (wyników przeprowadzonych typologii jedno- i wielocechowej).

Realizacja przedstawionego zakresu problemowego badań warunków mieszkaniowych wymagała stosownych materiałów źródłowych.

W początkowym okresie badania warunków mieszkaniowych prowadzono korzystając $\mathrm{z}$ bardzo szczegółowych materiałów źródłowych pochodzących z kart ewidencji poszczególnych budynków. Sporządzano je m.in. na potrzeby studium inwentaryzacji urbanistycznej. Wymagały one weryfikacji i uzupełnienia $\mathrm{w}$ trakcie obserwacji i wywiadów prowadzonych bezpośrednio w terenie. Karty budynków niejednokrotnie były niekompletne i obarczone błędnymi zapisami m.in. dotyczącymi kubatury, powierzchni zabudowy, powierzchni użytkowej lokali mieszkalnych, liczby kondygnacji, roku zakończenia budowy itp. Dlatego wymagały one weryfikacji i uzupełnienia poprzez obserwację i wywiady terenowe oraz o odpisy z różnorodnych dokumentów. W oparciu o obserwacje w terenie określano m.in. lokalizację szczegółową budynków, sposób ich użytkowania, materiał ścian, pokrycia dachu, podpiwniczenie, stan techniczny, liczbę kondygnacji, wyposażenie w instytucje usługowe, administracyjne i gospodarcze. $Z$ kolei poprzez wywiad ustalano ostatecznie własność, wyposażenie sanitarno-techniczne, strukturę i wyposażenie mieszkań itp. oraz uzupełniano informacje o liczbie ludności i strukturze rodzin zamieszkujących poszczególne budynki. Prowadzono także szerokie kwerendy w różnorodnych instytucjach, np. korzystając z książek meldunkowych i in.

Wykorzystywane w badaniach warunków mieszkaniowych wskazane materiały źródłowe miały swoje zalety, ale też i wady. Cechowały się na ogół niejednolitym zakresem rzeczowym i czasowym informacji, różnorodną przynależnością instytucjonalną, niejednorodnością i nierównoważną wartością poznawczą, niekompletnym, niedokładnym i niepewnym zestawem niektórych danych oraz często subiektywnym zabarwieniem badanych elementów. Dlatego korzystanie z nich wymagało pewnego przygotowania teoretycznego i praktyki badawczej, zwłaszcza na poziomie wytypowania tych danych, które należało zweryfikować w toku szczegółowych prac terenowych. Umożliwiały one jednak przeprowadzenie szczegółowych analiz i ocen oraz rejonizacji przestrzennej nie tylko całego obszaru miasta (Niemodlin, Prudnik), ale także jego fragmentu (Kielce).

Objęcie analizą oceniającą stan i zróżnicowanie przestrzenne warunków mieszkaniowych Łodzi umożliwiały od 1970 r. dane Narodowych Spisów Powszechnych (NSP), których wyniki m.in. dotyczące warunków mieszkaniowych początkowo udostępniano w podziale na 90 jednostek urbanistycznych, 
a później na 61 jednostek osiedlowych Łodzi. Seria przygotowanych publikacji w okresie od końca lat 70. do początku pierwszej dekady XXI wieku (Dzieciuchowicz 1974a, 1976, 1979, 1980, 1999, 2002, 2011a) została m.in. oparta na materiałach Narodowych Spisów Powszechnych. Materiały NSP uzupełniano danymi pochodzącymi z mikrospisów ludności i mieszkań, z bieżącej i okresowej ewidencji statystycznej zasobów mieszkaniowych i budownictwa mieszkaniowego. W ostatnim okresie informacje te publikowane są w Statystyce Łodzi, Rocznikach statystycznych województwa łódzkiego oraz udostępniane bezpośrednio przez Urząd Statystyczny w Łodzi, a także są zawarte i udostępniane w Banku Danych Lokalnych GUS.

Końcówka pierwszej dekady XXI wieku i nieudany NSP z 2011 r. spowodowały konieczność podjęcia szerszych kwerend w zarządach spółdzielni mieszkaniowych oraz budynków komunalnych. Na nich oparto analizy oceniające stan i zróżnicowanie przestrzenne spółdzielczych i komunalnych zasobów mieszkaniowych Łodzi (Dzieciuchowicz 2005, 2007a, 2007b, 2011b). Z kolei zainteresowanie Autora problemem nieruchomości gruntowych i obrotem nimi spowodowało zainteresowanie materiałami źródłowymi pochodzącymi z ewidencji gruntów a posiadanymi i gromadzonymi przez Miejski Ośrodek Dokumentacji Geodezyjnej i Kartograficznej (MODGiK) oraz Miejskie Przedsiębiorstwo Geodezyjne w Łodzi (Dzieciuchowicz 2008, 2011a). Obejmują one dane dotyczące grup i podgrup rejestrowanych działek zawierające ich liczbę, wielkość, formę użytkowania i własność w podziale na 215 obrębów geodezyjnych. Geodezyjna klasyfikacja użytkowania ziemi wyróżnia 24 użytki gruntowe, zestawione w siedem głównych rodzajów użytków obejmujących grunty zabudowane i zurbanizowane (w tym mieszkaniowe), użytki rolne, tereny leśne, grunty pod wodami, użytki ekologiczne, nieużytki i tereny różne. J. Dzieciuchowicz uważa, że zaletą tej klasyfikacji jest stabilność i wiarygodność, ponieważ opiera się ona na ściśle określonych i względnie trwałych podstawach prawnych. Daje ona możliwość prowadzenia badań użytkowania ziemi w miastach w różnych skalach przestrzennych (co m.in. dowodzi rozprawa doktorska R. Gotowskiego 2008), a także w ujęciu retrospektywnym. Za wadę tej klasyfikacji uznaje wyższy poziom generalizacji niż ma to miejsce w jej odpowiednikach geograficznych i urbanistycznych. MODGiK w Lodzi prowadzi bazę danych o gruntach i budynkach, zawierającą m.in. informacje o obrocie nieruchomościami (od lat 60. XX w.), na których m.in. oparto analizę obrotu (kupno-sprzedaż) nieruchomościami w Łodzi w latach 2004-2005. W analizach rozwoju i otoczenia łódzkiego rynku nieruchomości przydatne okazały się też materiały statystyczne GUS umożliwiające badanie dynamiki i zróżnicowania przestrzennego obrotu nieruchomościami według ich rodzajów w skali Polski.

Pozyskane w opisany sposób materiały źródłowe wymagały stosownych metod analizy. Ponieważ miały one charakter ilościowy, naturalną rzeczą w ich analizie było szerokie wykorzystanie dostępnych metod statystycznych i ich umiejętna adaptacja do badań zróżnicowania przestrzennego warunków 
mieszkaniowych miast. W analizach zróżnicowania przestrzennego tych warunków wykorzystano wskaźniki statystyki opisowej, takie jak ilorazowe, zmienności, asymetrii, kurtozę, korelacji, funkcję regresji oraz statystyczne metody typologii, jak koncentracji, względnych odchyleń od średniej, ekonometryczną metodę zaproponowaną przez S. Bartosiewiczową (1976), metodę transformacji liniowej szeregów terytorialnych, metodę grupowania hierarchicznego Warda, diagram Czekanowskiego i metodę $k$-średnich.

W artykule (Dzieciuchowicz i in. 1972) przedstawiającym szczegółową rejonizację warunków mieszkaniowych centrum Kielc obok zdefiniowania pojęcia warunki mieszkaniowe oraz idei i sposobu ich oceny, zdefiniowano także pojęcie rejonu warunków mieszkaniowych. Pod pojęciem rejonu warunków mieszkaniowych rozumiano obszar składający się z przylegających do siebie jednostek przestrzennych (bloków urbanistycznych), których cechy warunków mieszkaniowych są, w mniejszym lub większym stopniu podobne. W ten sposób można wydzielić zarówno jednocechowe, jak i wielocechowe rejony warunków mieszkaniowych. Wartości cech wyrażono w stosunku do wielkości przeciętnych dla całego obszaru. Warunki mieszkaniowe w określonej jednostce przestrzennej traktowano jako dobre lub złe, wówczas gdy wartości analizowanych cech były odpowiednio wyższe lub niższe od wartości przeciętnej. Natomiast wartości cech określonej jednostki przestrzennej zbliżone do wartości przeciętnych dla analizowanego obszaru określono jako średnie. Do wydzielenia rejonów warunków mieszkaniowych centrum Kielc posłużono się geograficzno-ekonomiczną metodą względnych odchyleń oraz statystyczną metodą koncentracji.

W opracowaniach (Dzieciuchowicz 1972, 1974b) omawiających warunki mieszkaniowe w małych miastach Śląska Opolskiego (Niemodlin, Prudnik), a bazujących na materiałach $\mathrm{z}$ inwentaryzacji terenowej zabudowy mieszkaniowej i podejmujących charakterystykę tej zabudowy wraz ze wskazaniem na jej zróżnicowanie przestrzenne, wykorzystano statystyczną miarę koncentracji. Umożliwiła ona pomiar skupienia budynków mieszkalnych na obszarze Niemodlina (według bloków urbanistycznych) z podziałem na zabudowę ogółem oraz jej składowe: zabudowę wielorodzinną, jednorodzinną i zagrodową oraz zamieszkującą ją ludność. Z kolei przestrzenną ocenę sytuacji mieszkaniowej Niemodlina wykonano w oparciu o czteropolowy (pola A, B, C, D) wykres typologiczny (z rzędną obrazującą liczbę osób przypadającą na 1 izbę, odciętą ilustrującą wielkość powierzchni użytkowej mieszkań w przeliczeniu na 1 osobę). Dobre warunki mieszkaniowe określała duża powierzchnia mieszkań i małe zaludnienie izb (pole D), z kolei złe warunki identyfikowano $\mathrm{z}$ małą powierzchnią mieszkań i dużym zaludnieniem izb (pole B). W polach A i C wykresu typologicznego znalazły się bloki urbanistyczne o średnich wartościach warunków mieszkaniowych. W przypadku analizy zróżnicowania przestrzennego warunków mieszkaniowych Prudnika poprzestano na opisie rozkładu i zróżnicowania przestrzennego statystycznych wskaźników opisujących te warunki. Wprowadzono interesujący wskaźnik porównujący liczbę rodzin 
i liczbę mieszkań. Rozbieżności pomiędzy liczbą rodzin i mieszkań wskazują na niedobór lub nadmiar mieszkań i są dobrym wskaźnikiem warunków mieszkaniowych.

W pierwszych opracowaniach dotyczących warunków mieszkaniowych Łodzi, np. w latach 1945-1965 (Dzieciuchowicz 1974a), a następnie w niektórych późniejszych (Dzieciuchowicz 1976, 1979, 1980, 2000, 2002, 2011a), wykorzystano dane spisowe i wskaźniki statystyki opisowej do ogólnej analizy warunków mieszkaniowych Łodzi oraz ich zróżnicowania przestrzennego w układzie, początkowo 90 jednostek urbanistycznych, a później 61 jednostek osiedlowych. Kolejne prace dotyczące warunków mieszkaniowych Łodzi koncentrują uwagę na problemie szczegółowej i kompleksowej rejonizacji tych warunków w okresach spisowych. Dwie pierwsze (Dzieciuchowicz 1979, 1980) podejmujące problem kompleksowej rejonizacji warunków mieszkaniowych Łodzi wykorzystują dane spisowe i metodę transformacji liniowej szeregów terytorialnych A.A. Robinsona i R.A. Brysona, rozwiniętą i zmodyfikowaną przez R. Domańskiego. Z kolei do przeprowadzenia kompleksowej oceny poziomu standardu mieszkaniowego jednostek urbanistycznych, w oparciu o dane spisowe, wykorzystano metodę ekonometryczną przedstawioną przez S. Bartosiewiczową (1976). Metoda ta (Dzieciuchowicz 2002) umożliwia pomiar standardu mieszkaniowego za pomocą jednej zmiennej syntetycznej. Natomiast identyfikację jednostek urbanistycznych podobnych ze względu na badane cechy standardu mieszkaniowego dokonano przy pomocy taksonomicznej metody grupowania hierarchicznego Warda (wykorzystano pakiet statystyczny Statgraphics Plus). Charakterystykę zróżnicowań przestrzennych budownictwa spółdzielczego oparto na miarach statystyki opisowej, a w jego typologii skorzystano z metody grupowania hierarchicznego Warda (Dzieciuchowicz 2005). W kolejnych artykułach waloryzację przestrzenną i typologię warunków mieszkaniowych w budownictwie komunalnym i społecznym opracowano przy użyciu metody J. Czekanowskiego wykorzystując program komputerowy MaCzek ver. 3.3. (Dzieciuchowicz 2007a, 2007b, 2011b). Z kolei w typologii przestrzennej nieruchomości gruntowych w Łodzi wykorzystano taksonomiczną metodę $k$-średnich, szczególnie przydatną przy operowaniu dużymi zbiorami jednostek terytorialnych (215 obrębów geodezyjnych), udostępnioną w programie statystycznym SPSS (Dzieciuchowicz 2011a). Wszystkie opracowania zawierają kartogramy, kartodiagramy i wykresy prezentujące przeprowadzone analizy przy wykorzystaniu wskaźników statystyki opisowej i wskazanych metod typologicznych.

Wyniki przeprowadzonych badań warunków mieszkaniowych przy wykorzystaniu wskazanych materiałów źródłowych i metod ich analizy uzależnione są w znaczącym stopniu od uwzględnionego zestawu cech opisujących te warunki. W opisie i analizach warunków mieszkaniowych wykorzystano zarówno cechy wewnętrzne (wiek, standard techniczny, formy własności, wielkość, wyposażenie sanitarno-techniczne, koszty użytkowania, zaludnienie 
lokali mieszkalnych i in.), jak i zewnętrzne (intensywność zabudowy, wielkość budynków, powierzchnię i formy własności nieruchomości gruntowych i in.) rejestrowane w obszarze otaczającym mieszkania. Zapewniają one poprawność przeprowadzonych analiz i odpowiednią ich szczegółowość oraz możliwość ich syntezy.

Uzyskane wyniki w omawianych opracowaniach są interesujące. Odnośnie analiz przeprowadzonych w małych miastach (Dzieciuchowicz 1972, 1974b) uwagę zwraca wysoka koncentracja zasobów i duże zróżnicowanie warunków mieszkaniowych. Stara zabudowa, często nieprzystosowana do aktualnych potrzeb mieszkaniowych (m.in. ze względu na niski standard mieszkań), skupiała się w centralnej części małych miast opolskich. Natomiast zasoby o wyższym standardzie mieszkaniowym lokalizowały się $\mathrm{z}$ reguły $\mathrm{w}$ strefach zewnętrznych $\mathrm{w}$ stosunku do centrum i związane były $\mathrm{z}$ reguły $\mathrm{z}$ nowym budownictwem. W małych miastach Opolszczyzny zasoby mieszkaniowe ujawniały ich dziedzictwo historyczne, zwłaszcza okresy szybkiego ich rozwoju społeczno-ekonomicznego, które wyraźnie zapisały się $\mathrm{w}$ ich substancji mieszkaniowej. Z kolei analiza warunków mieszkaniowych centrum Kielc (Dzieciuchowicz i in. 1972) ujawniła wysoki poziom ich zróżnicowania na stosunkowo niedużym obszarze. Autorzy wyróżnili aż cztery rejony o zróżnicowanych warunkach mieszkaniowych: 1) północny - złych, 2) wschodni dobrych, 3) zachodni - średnich i 4) południowy - dobrych warunków mieszkaniowych.

Ze studiów przeprowadzonych nad warunkami mieszkaniowymi Łodzi wyłania się dość interesujący obraz (Dzieciuchowicz 1974a, 1975, 1976, 1979, 1980, 1999, 2002, 2005, 2007a, 2007b, 2008, 2011a, 2011b, 2012). Generalna poprawa warunków mieszkaniowych nastąpiła po drugiej wojnie światowej, która pozwoliła Łodzi osiągnąć ich stan porównywalny z innymi dużymi miastami Polski. W okresie poprzedzającym drugą wojnę światową Łódź była nagromadzeniem czynszowych kamienic, podwórek - studni, 1000 kominów, wąskich ulic, które stały się synonimem „złego miasta" - symbolu nędzy i brzydoty miejskiej. Utarł się pogląd, że Łódź w niewielkim stopniu uległa zniszczeniom w okresie drugiej wojny światowej. Jednak, po zakończeniu wojny tylko $10 \%$ budynków było w dobrym stanie. Stan pozostałych był zły, a aż $28 \%$ z nich groziło zawaleniem, z czego po remontach uratowano tylko 1/3. Do lat 70 . $\mathrm{XX}$ w. budownictwo mieszkaniowe koncentrowało się przede wszystkim na terenach północnych i południowych obrzeży śródmieścia, poprawie uległa zwłaszcza sytuacja mieszkaniowa Bałut. Poprawa warunków mieszkaniowych nastąpiła na obszarach pozaśródmiejskich, co sprzyjało względnemu pogorszeniu sytuacji mieszkaniowej śródmieścia. W ten sposób prowadzona polityka mieszkaniowa utrwalała pasmowy układ zabudowy. W kolejnych latach, po 1970 r. nastąpiła budowa szeregu dużych osiedli blokowych zlokalizowanych peryferyjnie w stosunku do śródmieścia, w którym podejmowano inwestycje mieszkaniowe na niewielką skalę (budynki plombowe i Śródmiejska Dzielnica 
Mieszkaniowa). Efektem tego było dalsze względne pogarszanie się warunków mieszkaniowych $\mathrm{w}$ śródmieściu $\mathrm{w}$ porównaniu $\mathrm{z}$ nowymi, peryferyjnie położonymi osiedlami blokowymi. W miarę upływu czasu w rozwoju przestrzennym zasobów mieszkaniowych Łodzi nasilała się tendencja odśrodkowa, która doprowadziła do wytworzenia się koncentryczno-sektorowego typu układu całej zabudowy mieszkaniowej miasta (ryc. 1). W części centralnej miasta (śródmieście) dominowały obszary o dobrych warunkach mieszkaniowych. Centralną część miasta bezpośrednio otaczała strefa pośrednia, w której w równym niemal udziale występowały dobre, średnie i złe warunki mieszkaniowe. Strefę pośrednią otaczała strefa peryferyjna posiadająca średnie i złe warunki mieszkaniowe. Z kolei $\mathrm{w}$ okresie transformacji ustrojowej notuje się pewien zastój w budownictwie mieszkaniowym w porównaniu z okresem lat 1970-1989, przez co zmiany w układzie przestrzennym zasobów mieszkaniowych były niewielkie w porównaniu $\mathrm{z}$ okresem sprzed transformacji ustrojowej, co sprzyjało zachowaniu dotychczasowego układu przestrzennego zasobów mieszkaniowych Łodzi. Natomiast fundamentalnym przekształceniom podlegała struktura własności mieszkań.

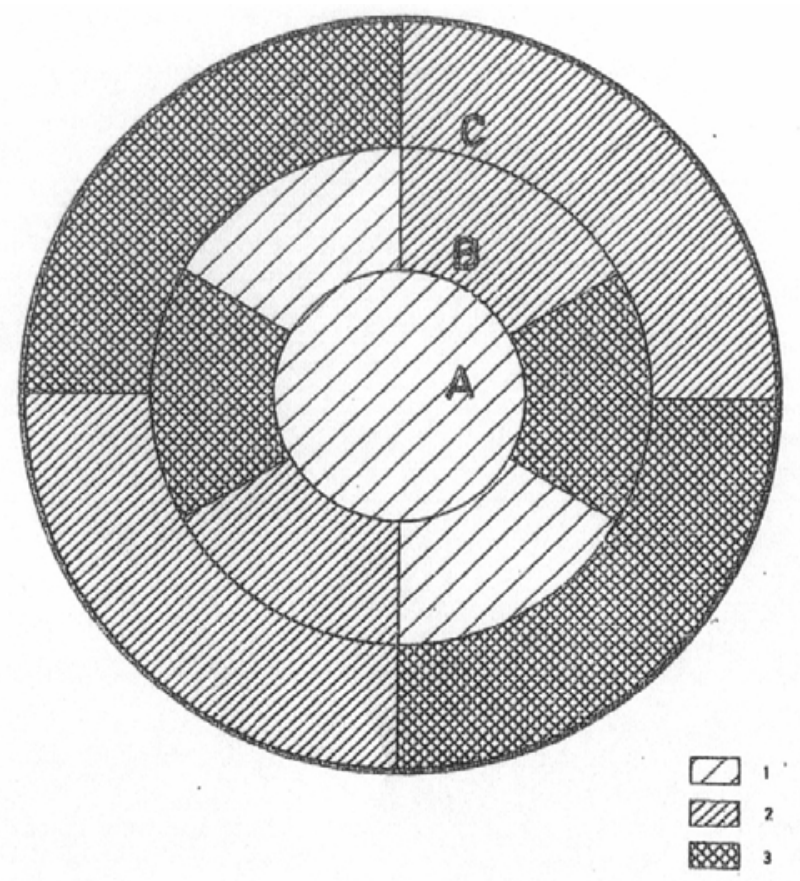

Ryc. 1. Model rejonizacji warunków mieszkaniowych ludności Łodzi według J. Dzieciuchowicza (1976)

A - strefa śródmiejska, B - strefa pośrednia, C - strefa peryferyjna; 1 - warunki dobre, 2 - warunki średnie, 3 - warunki złe 
W 2011 r. J. Dzieciuchowicz (2011a) opublikował książkę zatytułowaną Środowisko mieszkaniowe wielkiego miasta. Przykład Łodzi. Zawiera ona szereg empirycznych analiz zasobów mieszkaniowych Łodzi w okresie transformacji ustrojowej oraz analizę empiryczną trzech czynników kształtujących te zasoby, a mianowicie nieruchomości gruntowe, obrót rynkowy nimi i układ sieci drogowej miasta. Metodologia empirycznej części pracy nawiązuje do dotychczasowych opracowań Autora omówionych wcześniej. W tej książce uwagę czytelnika przyciąga m.in. bardzo zwięzła część teoretyczna, w której zaproponowano szeroko ujęty model środowiska mieszkaniowego. Jest to, po wielu latach szczegółowych badań empirycznych, pewna próba syntetycznego spojrzenia na geograficzne badania mieszkalnictwa obejmująca cztery główne, powiązane ze sobą dziedziny, tj. środowisko mieszkaniowe, przestrzeń mieszkaniową, warunki mieszkaniowe oraz potrzeby i preferencje mieszkaniowe.

Przyjęto założenie systemowe, że badania geograficzne środowiska mieszkaniowego obejmują złożony układ sześciu podstawowych elementów, tj. terenów, zasobów, budownictwa, polityki i gospodarki mieszkaniowej oraz użytkowników mieszkań. Wszystkie wymienione elementy powiązane są wzajemnymi relacjami, ponieważ żaden $\mathrm{z}$ nich nie funkcjonuje $\mathrm{w}$ pełni samodzielnie, niezależnie od pozostałych. Tak określone środowisko mieszkaniowe powiązane jest układem złożonych relacji z otoczeniem (stanowiącym determinanty jego funkcjonowania) obejmującym położenie geograficzne i warunki przyrodnicze, czynniki historyczne i polityczne, gospodarcze, społeczne i kulturowe (ryc. 2). Środowisko mieszkaniowe może być badane w ujęciu statycznym lub dynamicznym. Analizy przestrzenne środowiska mieszkaniowego obejmują kierunki i dynamikę przemian poszczególnych jego elementów, w tym także waloryzację i typologię przestrzenną oraz rejonizację terenów, zasobów i warunków mieszkaniowych.

Przestrzeń mieszkaniowa, będąca formą istnienia i przekształceń terenów i zasobów mieszkaniowych $\mathrm{w}$ granicach przestrzeni społeczno-ekonomicznej, składa się z przestrzeni zajmowanej przez tereny mieszkaniowe oraz zabudowę mieszkaniową i ich użytkowników, a także z podmiotów prowadzących działalność w zakresie budownictwa mieszkaniowego i gospodarki mieszkaniowej oraz relacji przestrzennych zachodzących między nimi.

Dla badań geograficznych ważne są analizy terenów mieszkaniowych, które obejmują studia ich dyfuzji przestrzennej, intensywności pionowej i poziomej ich użytkowania oraz ich funkcję, fizjonomię i własność wraz $z$ obrotem rynkowym gruntami mieszkaniowymi i działkami budowlanymi oraz otaczającą je infrastrukturę społeczną i techniczną.

Warunki mieszkaniowe $\mathrm{w}$ tej książce określono zgodnie $\mathrm{z}$ terminologią wprowadzoną w opracowaniu współautorskim (Dzieciuchowicz, Stolarczyk, Suliborski 1972), co omówiono wcześniej. 


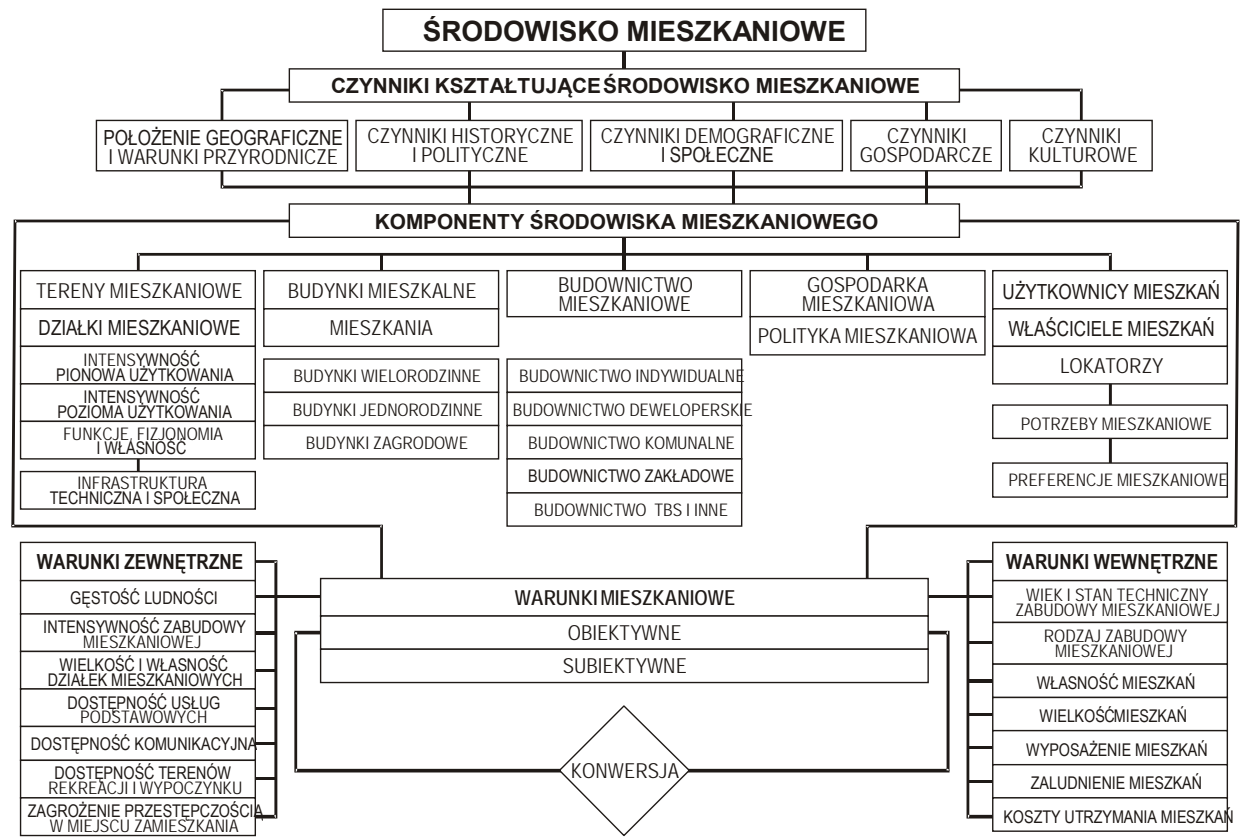

Ryc. 2. Model środowiska mieszkaniowego według J. Dzieciuchowicza (2011)

Potrzeby mieszkaniowe należą do kategorii najważniejszych potrzeb ludzkich. Określa je rozmiar efektywnego popytu na mieszkania (ujęcie liberalne) lub stosunek liczby gospodarstw domowych i mieszkań (ujęcie normatywne) informujący o rozmiarach zaspokojenia lub niezaspokojenia potrzeb mieszkaniowych. Potrzeby mieszkaniowe są zmienne w czasie i przestrzeni, w wysokim stopniu zindywidualizowane i uzależnione od cech demograficznych, społecznych, ekonomicznych i kulturowych.

Preferencje mieszkaniowe oznaczają przedkładanie przez określone gospodarstwo domowe jednego mieszkania nad inne, a więc dotyczą wyboru lokalu, rodzaju zabudowy, ich otoczenia społeczno-ekonomicznego (infrastruktura, sąsiedztwo itp.) i są uwarunkowane wieloma zmiennymi (demograficznymi, społecznymi, ekonomicznymi, kulturowymi, przestrzennymi, wyobrażeniami itp.).

Tak zarysowana problematyka badań geograficznych mieszkalnictwa bardzo trudno poddaje się badaniom kompleksowym (pełnym), natomiast dużo łatwiej badać można $\mathrm{z}$ osobna każdy z wymienionych elementów tego układu, co zaprezentowano w części empirycznej książki. 


\subsection{PODSUMOWANIE}

Geografowie z ośrodka łódzkiego przeprowadzili szereg studiów inwentaryzacji urbanistycznej w miastach Śląska Opolskiego, Kielc i Łodzi. Na ich podstawie przedstawiono szereg opracowań dotyczących zróżnicowania przestrzennego i szczegółowej rejonizacji warunków mieszkaniowych w paru miastach Śląska Opolskiego, centrum Kielc oraz w Łodzi. Zdefiniowano pojęcie środowiska mieszkaniowego i zaproponowano systemowe podejście do jego badań. Badania te oparto na bezpośrednich kwerendach terenowych oraz na materiałach Narodowych Spisów Powszechnych (NSP). W badaniach tych aktywny udział brał Profesor Jerzy Dzieciuchowicz. Problematyka mieszkalnictwa, a zwłaszcza rejonizacja warunków mieszkaniowych w Łodzi, stanowi w dorobku naukowym Profesora ważny nurt badawczy w okresie 1972-2012. Przeprowadzone $\mathrm{w}$ tym okresie studia empiryczne podsumowuje propozycją badań mieszkalnictwa w postaci szeroko ujętego modelu środowiska mieszkaniowego.

\section{LITERATURA}

Adamczewska-Wejchert H., 1977, Zasady budowy miast, Arkady, Warszawa.

Bachvarov M., 2005, Osiedla zamknięte - „getta” z wyboru [w:] Jażdżewska I. (red.), Wspótczesne procesy urbanizacji $i$ ich skutki, „XVIII Konwersatorium Wiedzy o Mieście", Łódź, s. 235-244.

Bartosiewicz S., 1976, Ekonometria. Technologia ekonometrycznego przetwarzania danych, PWE, Warszawa.

Dzieciuchowicz J., 1972, Warunki mieszkaniowe w Niemodlinie, „Opolskie Roczniki Ekonomiczne" 4, s. 215-234.

Dzieciuchowicz J., Stolarczyk B., Suliborski A., 1972, Warunki mieszkaniowe Kielc w ujęciu przestrzennym. ,Zeszyty Naukowe UŁ” 2(49), s. 37-65.

Dzieciuchowicz J., 1974a, Rozwój budownictwa mieszkaniowego $w$ Łodzi w latach 1945-1965 oraz jego wplyw na zmiany warunków mieszkaniowych ludności, „Zeszyty Naukowe UŁ” 2(55), s. 31-47.

Dzieciuchowicz J., 1974b, Zabudowa mieszkaniowa Prudnika, „Zeszyty Naukowe UŁ” 2(55), s. 79-94.

Dzieciuchowicz J., 1975, Ksztattowanie warunków środowiska mieszkaniowego wielkiego miasta na przykładzie Lodzi, XIII Ogólnopolski Zjazd PTG, Tezy i streszczenia referatów, Łódź, s. 66-68.

Dzieciuchowicz J., 1976, Szczegótowa rejonizacja warunków mieszkaniowych ludności Łodzi w roku 1970, „Acta Universitatis Lodziensis” 2(7), s. 3-40.

Dzieciuchowicz J., 1979, Ksztattowanie warunków mieszkaniowych wielkiego miasta na przyktadzie Łodzi, „Acta Universitatis Lodziensis” 2(21), s. 69-79.

Dzieciuchowicz J., 1980, Kompleksowa rejonizacja warunków mieszkaniowych ludności wielkiego miasta (przykład Łodzi), „Acta Universitatis Lodziensis” 2(22), s. 21-38. 
Dzieciuchowicz J., 1999, Ewolucja i typologia przestrzenna budownictwa mieszkaniowego w Łodzi [w:] Nauki geograficzne a edukacja społeczna, „Region Łódzki” 2, PTG UŁ, Łódź, s. 89-95.

Dzieciuchowicz J., 2000, Spatial structure and typology of co-operative housing in Łódź [w:] Contemporary Role of the Service Sector, „Przestrzeń-SpołeczeństwoGospodarka”, Studia i Materiały KGPiPP UŁ 5, Abstract of the Conference, s. $96-100$.

Dzieciuchowicz J., 2002, Zasoby mieszkaniowe Łodzi: rozwój, struktura przedmiotowa i przestrzenna, „Acta Universitatis Lodziensis. Folia Geographica Socio-Oeconomica” 4, Wydawnictwo UŁ, Łódź, s. 47-65.

Dzieciuchowicz J., 2005, Spółdzielcze budownictwo mieszkaniowe w Łodzi - struktura i typologia przestrzenna, „Acta Universitatis Lodziensis. Folia Geographica Socio-Oeconomica” 6, Wydawnictwo UŁ, Łódź, s. 69-94.

Dzieciuchowicz J., 2007a, Budownictwo komunalne w Łodzi - struktura przestrzenna, „Acta Universitatis Lodziensis. Folia Geographica Socio-Oeconomica” 8, Wydawnictwo UŁ, Łódź, s. 103-125.

Dzieciuchowicz J., 2007b, Waloryzacja i typologia przestrzenna budownictwa komunalnego $w$ Łodzi, „Acta Universitatis Lodziensis. Folia Geographica Socio-Oeconomica” 8, Wydawnictwo UŁ, Łódź, s. 127-136.

Dzieciuchowicz J., 2008, Obrót nieruchomościami gruntowymi na terenie Łodzi, „Acta Universitatis Lodziensis. Folia Geographica Socio-Oeconomica” 9, Wydawnictwo UŁ, Łódź, s. 123-146.

Dzieciuchowicz J., 2011a, Środowisko mieszkaniowe wielkiego miasta. Przykład Łodzi, Wydawnictwo UŁ, Łódź, 219 s.

Dzieciuchowicz J., 2011b, Społeczne budownictwo mieszkaniowe w Łodzi - rozwój, zasoby mieszkaniowe i ich użytkownicy [w:] Dzieciuchowicz J. (red.), Współczesne przemiany środowiska mieszkaniowego - wybrane problemy, „Space-Society-Economy” 10, Wydawnictwo UŁ, Łódź, s. 115-141.

Dzieciuchowicz J., 2012, Valorization and spatial typology of tódźs residential resources during the transformation period [w:] Dzieciuchowicz J., Groeger L. (red.), Kształtowanie przestrzeni mieszkaniowej miast. Shaping the Urban Residential Area, „Space-Society-Economy” 11, Department of Spatial Economy and Spatial Planning, Wydawnictwo UŁ, s. 35-47.

Dzieciuchowicz J., Groeger L. (red.), 2012, Kształtowanie przestrzeni mieszkaniowej miast. Shaping the urban residential area, ,Space-Society-Economy” 11, Wydawnictwo UŁ, Łódź, 236 s.

Dutkowski M., Sagan I., 1987, O zróżnicowaniu morfologicznym przestrzeni mieszkaniowej Sopotu, „Rocznik Sopocki 1982-1984”, Sopot.

Gotowski R., 2008, Struktura funkcjonalno-przestrzenna Bydgoszczy, Rękopis rozprawy doktorskiej, IGMiT UŁ, Łódź.

Gray F., 1975, Non-explanation in urban geography, „Area” 7, s. 228-234. Tłumaczenie polskie w: Przegląd Zagranicznej Literatury Geograficznej, 1980, z. 1, s. 48-60.

Groeger L., 2004, Waloryzacja przestrzeni mieszkaniowej w opiniach klientów łódzkich biur obrotu nieruchomościami, Wydawnictwo UŁ, Łódź, 127 s. 
Groeger L., 2013, Zróżnicowanie i wartościowanie przestrzeni mieszkaniowej na przykładzie miast województwa łódzkiego, Wydawnictwo UŁ, Łódź, 255 s.

Harvey D., 1973, Social justice and the city, Edward Arnold, London.

Harvey D., 1975, Class structure in a capitalist society and the theory of residential differentiation [w:] Peel R., Chisholm M., Haggett P. (red.), Processes in physical and human geography, Heinemann, London, s. 354-369. Tłumaczenie polskie w: Przegląd Zagranicznej Literatury Geograficznej, 1980, z. 1, s. 38-47.

Jałowiecki B., 1968, Osiedle i miasto. Studium socjologiczno-urbanistyczne jednostek mieszkaniowych Wrocławia, Warszawa.

Johnston R.J., 1977, Urban geography; city structures, „Progress in Human Geography” 1(1), s. 118-129. Tłumaczenie polskie w: Przegląd Zagranicznej Literatury Geograficznej, 1980, z. 1, s. 21-37.

Kaczmarek S., 1996, Struktura przestrzenna warunków zamieszkania w Lodzi, „Szlakami Nauki” 23, ŁTN, Łódź, 85 s.

Kucharska M., 1974, Struktura demograficzna i zatrudnienie mieszkańców osiedla Teofilów „A ” w Łodzi, ,Zeszyty Naukowe UŁ” 2, Nauki Matematyczno-Przyrodnicze, 55, s. 49-64.

Liszewski S., 1971, Studia inwentaryzacji urbanistycznej miast. Zakres i metody pracy, „Opolskie Roczniki Ekonomiczne” 3 (1970-71), Polskie Towarzystwo Ekonomiczne. Oddział w Opolu, Opole, s. 257-261.

Liszewski S., 1995, Zróżnicowane przestrzenne poziomu i jakości warunków życia ludności w aglomeracjach miejskich (program badań, pierwsze wyniki), „Acta Universitatis Lodziensis. Folia Geographica” 20, Wydawnictwo UŁ, Łódź.

Madurowicz M. (red.), 2007, Percepcja współczesnej przestrzeni miejskiej, Wydawnictwo UW, Warszawa.

Marcińczak S., 2004, Ocena warunków zamieszkania w opinii mieszkańców osiedla im. M. Mireckiego $w$ Lodzi [w:] Jażdżewska I. (red.), Zróżnicowanie warunków życia ludności w mieście, „XVII Konwersatorium Wiedzy o Mieście”, Wydawnictwo UŁ, Łódź.

Marszał T., 1999, Budownictwo mieszkaniowe w latach dziewięćdziesiątych - zróżnicowanie przestrzenne i kierunki rozwoju, „Biuletyn KPZK PAN” 190, Warszawa.

Mierzejewska L., 2006, Osiedla zamknięte jako nowe przestrzenie miast polskich (przyktad Poznania) [w:] Jażdżewska I. (red.), Nowe przestrzenie $w$ mieście, ich organizacja i funkcje, „XIX Konwersatorium Wiedzy o Mieście”, Łódź, s. 311-320.

Milewska-Osiecka K., 2010, Budownictwo mieszkaniowe $w$ aglomeracji łódzkiej (zróżnicowanie i struktura przestrzenna po roku 1994), Łódź.

Ogrodowczyk A., 2011, Polityka przestrzenna a rozwój budownictwa mieszkaniowego po 1990 roku na przykładzie małych miast $w$ województwie tódzkim, „Acta Universitatis Lodziensis. Folia Geographica Socio-Oeconomica” 11, Wydawnictwo UŁ, Łódź, s. 167-186.

Pączka S., 1971, Działalność geografów Uniwersytetu Łódzkiego w województwie opolskim w latach 1958-1968, „Studia Społeczno-Ekonomiczne” 2, s. 261-273. 
Przesmycka E., Pytlarz E., 2006, Współczesne standardy w budownictwie mieszkaniowym w Polsce [w:] Tokajuk A., Zaniewska H. (red.), Tendencje w kształtowaniu zabudowy mieszkaniowej współczesnych miast, Wydział Architektury Politechniki Białostockiej, Białystok.

Suliborski A., 1970, Struktura przestrzenna osiedla mieszkaniowego Julianów w Łodzi, „Zeszyty Naukowe UŁ” 2, Nauki Matematyczno-Przyrodnicze 38 - Geografia Ekonomiczna, s. 91-108.

Suliborski A., 1976, Środowisko mieszkaniowe miasta jako przedmiot badań geografii osadnictwa, „Acta Universitatis Lodziensis” 2(7).

Szafrańska E., 2010, Przemiany struktury społeczno-przestrzennej i funkcjonalnej wielkich zespołów mieszkaniowych $w$ mieście postsocjalistycznym. Przykład Łodzi, „Studia Miejskie” 2, Wydawnictwo UO, Opole.

Szafrańska E., 2011, Wielkie osiedla mieszkaniowe w okresie transformacji - próba diagnozy i kierunki przemian na przykładzie Łodzi [w:] Osiedla blokowe w strukturze przestrzennej miast, „XXIII Konwersatorium Wiedzy o Mieście”, Wydawnictwo UŁ, Łódź.

Szafrańska E., 2012, Niechciane dziedzictwo, czyli wielkie zespoly mieszkaniowe w strukturze społeczno-przestrzennej postsocjalistycznej Łodzi, „Acta Universitatis Lodziensis”, Folia Sociologica 36, Wydawnictwo UŁ, Łódź.

Szkurłat E., 2000, Akceptacja miejsca zamieszkania w Łodzi, Warszawie, Krakowie studium porównawcze [w:] Jażdżewska I. (red.), Miasto postsocjalistyczne, organizacja przestrzeni miejskiej i jej przemiany, „XIII Konwersatorium Wiedzy o Mieście, Łódź, s. 215-222.

Szmytkowska M., 2004, Warunki mieszkaniowe jako istotny wyznacznik społeczno-przestrzennej polaryzacji miast [w:] Jażdżewska I. (red.), Zróżnicowanie warunków życia w mieście, „XVII Konwersatorium Wiedzy o Mieście”, Łódź, s. 215-225.

Turowski J., 1979, Środowisko mieszkalne w świadomości ludności miejskiej, Ossolineum, Wrocław.

Węcławowicz G., 1980, Kierunki badań struktur społeczno-przestrzennych w geografii miast, „Przegląd Geograficzny” 53(4), s. 809-815.

\section{AbSTRACT}

In Poland after World War II the inventory of the overall condition of houses and flats in cities and towns was made as a part of the study of urban inventory. The Lódź center of geographical sciences contributed to this study actively. Geographers from the Łódź center carried out a series of urban inventory studies in the cities and towns of Opole Silesia and in Kielce and Łódź. On the basis of these studies, a series of monographs concerning the spatial diversity and detailed zoning of housing conditions in several cities and towns of Opole Silesia, in the center of Kielce and in Łódź was presented. The studies were based on direct fieldwork surveys and on data coming from the national censuses. Professor Jerzy Dzieciuchowicz participated actively in all these studies. The issue of housing, and particularly the zoning of housing conditions in Łódź, constituted an important field of research conducted by 
Professor in the period from 1972 to 2012. The presentation of a systemic proposal for such research summarizes the empirical studies carried out in this period. The above-mentioned proposal took the form of the model of housing environment.

KEYWORDS: city, housing, zoning of housing conditions 